13. Calmès C., Théoret R. Market-oriented banking, financial stability and macro-prudential indicators of leverage. Journal of International Financial Markets, Institutions and Money. 2013. № 27(1). P. 13-34.

\title{
References
}

1.Cerchiello P., Giudici P. Conditional graphical models for systemic risk estimation. Expert Systems with Applications, 2015 , no. 43, pp.165-174. doi:10.1016/j.eswa.2015.08.047

2.Cerchiello P., Giudici P. Big data analysis for financial risk management. Journal of Big Data, 2016 , vol.3, no. 1. doi:10.1186/s40537-016-0053-4.

3. Acharya V.V. A theory of systemic risk and design of prudential bank regulation. Journal of Financial Stability, 2009, vol.5, no. 3, pp. 224-255. doi: 10.1016/j.jfs.2009.02.001.

4.Brownlees C.T., Engle R.F. Volatility, Correlation and Tails for Systemic Risk Measurement. SSRN Electronic Journal, 2012, doi:10.2139/ssrn.1611229.

5.Brownlees C., Engle R.F. SRISK: A conditional capital shortfall measure of systemic risk. Review of Financial Studies, 2017 , vol. 30, no. 1, pp. 48-79. doi:10.1093/rfs/hhw060.

6.Lavreniuk V.V., Shevchuk V.V. Sutnist ta otsinka systemnoho ryzyku z pozytsii likvidnosti bankivskoi systemy. Problemy ekonomiky, 2016, no. 4, pp. 213-222 [in Ukrainian].

7.Systemic Risks: Measures and Determinants. Retrieved from https://core.ac.uk/download/pdf/30046821.pdf (accessed 15.06.2020) 8.Pokataieva O.V., Slavkina M.A. Otsiniuvannia systemnoho ryzyku yak instrument zabezpechennia ekonomichnoi bezpeky bankivskoho sektoru natsionalnoi ekonomiky. Naukovyi visnyk Uzhhorodskoho natsionalnoho universytetu, 2019, no.23, pp. 157-161 [in Ukrainian].

9. Kubinschi M., Barnea D. Systemic risk impact on economic growth - The case of the CEE countries. Romanian Journal of Economic Forecasting, 2016, no.19, vol. 4, pp. 79-94 [in English].

10. Langfield S., Pagano M. Bank bias in Europe: Effects on systemic risk and growth. Economic Policy, 2016, no. 31, vol. 85, pp. 53-106. doi: 10.1093/epolic/eiv019 [in English].

11. Giudici P., Parisi L. Soverein risk in the Euro area: a multivariate stochastic process approach. Quantitative Finance, 2017, no. 17, vol. 12, pp. 1995-2008 [in English].

12. Carmassi J., Herring R. The Corporate Complexity of Global Systemically Important Banks. Journal of Financial Services Research, 2016, no. 49, vol. 2-3, pp. 175-201. doi: 10.1007/s10693-016-0251-4 [in English].

13. Calmès C., Théoret R. Market-oriented banking, financial stability and macro-prudential indicators of leverage. Journal of International Financial Markets, Institutions and Money, 2013, no. 27, vol. 1, pp. 13-34. doi: 10.1016/j.intfin.2013.07.004 [in English].

Дата подання публікації 03.07.2020 p.

УДК 331.108:332.12

Рекун Г.П., к.е.н., доцент Rekun G. Candidate of Economic Sciences, Associate Professor https://orcid.org/0000-0002-1734-7364 Меденець В.В., старший лаборант Medenets V. Senior Assistant https://orcid.org/0000-0002-2435-9689

\section{МЕХАНІЗМ УПРАВЛІННЯ СТРАТЕГІЧНИМИ РОЗРИВАМИ КАДРОВОГО ЗАБЕЗПЕЧЕННЯ РОЗВИТКУ РЕГІОНУ}

\author{
Харківський начіональний університет імені В.Н. Каразіна
}

Усвідомлення провідного значення кадрового забезпечення в суспільному виробництві, ключової ролі кадрових ресурсів в економічному зростанні країни - $\epsilon$ базовими компонентами в умовах поглиблення інтеграційних процесів. Інерційний розвиток секторів економіки регіонів України породжує асиметрію регіонального ринку праці, що в умовах нових можливостей та викликів стане загрозою для кадрового забезпечення країни в цілому. Виходячи з актуальності запропонованої тематики, стаття присвячена обгрунтуванню механізму управління стратегічними розривами кадрового забезпечення території на прикладі Харківського регіону.

В статті запропоновано механізм управління стратегічними розривами кадрового забезпечення розвитку регіону, що уявляє собою складну інтегровану систему, елементами якого є: мета, завдання, принципи, функції, форми, методи, інструменти та передумови реалізації. Кожен структурний елемент механізму, обгрунтовано відповідно до загальних чинників управління кадровим забезпеченням та чинників ефективного управління та залучення стейкхолдерів. Адже управління стратегічними розривами кадрового забезпечення передбачає відхід від традиційних індикативних процесів планування й управління, та реалізацію стратегічних перетворень шляхом залучення стейкхолдерів території в зазначений процес й узгодження їх інтересів.

Також в статті запропоновано напрямки реалізації механізму управління стратегічними розривами кадрового забезпечення на основі попередньо проведених досліджень чинників, що детермінують появу 
«кадрових розривів». Розглянуто перешкоди на шляху до впровадження зазначеного механізму та шляхи їх вирішення.

Перспективами подальших досліджень у даному напрямі є визначення заходів практичної реалізації зазначеного механізму з метою подолання стратегічних розривів кадрового забезпечення Харківського регіону.

Ключові слова: механізм, стратегічні розриви, кадрові ресурси, кадрове забезпечення, регіон, стейкхолдери.

\title{
THE MECHANISM OF MANAGING THE STRATEGIC STAFFING GAPS THAT AFFECT THE DEVELOPMENT OF THE REGION
}

\author{
V.N. Karazin Kharkiv National University
}

\begin{abstract}
Awareness of the importance of human resources in a social production, the key role of human resources in the economic growth of the country are the main components in terms of deepening integration processes. The inertial development of the economic sectors of the regions of Ukraine creates an asymmetry in the regional labor market, which in the face of new opportunities and challenges will be a threat to the human resources of the country as a whole. Based on the relevance of the proposed topic, the article is devoted to the substantiation of the mechanism of managing the strategic staffing gaps that affect the development of the territory on the example of Kharkiv region.

The article proposes the mechanism of managing the strategic staffing gaps that affect the development of the region, which is a complex integrated system, whose elements are: purpose, objectives, principles, functions, forms, methods, tools and prerequisites for implementation. Each structural element of the mechanism is justified in accordance with the general factors of human resources management and the factors of effective management and involvement of stakeholders. After all, managing the strategic staffing gaps involves moving away from traditional indicative planning and management processes, and implementing strategic transformations by engaging territory stakeholders in the process and aligning their interests.

Also, the article proposes directions of implementation of the mechanism for managing the strategic staffing gaps based on previously conducted studies of factors that determine the emergence of "staffing gaps". The obstacles to the implementation of this mechanism and the possibilities of their solution are considered.

Prospects for further research in this area are to identify measures for the practical implementation of this mechanism in order to overcome he strategic staffing gaps of the Kharkiv region.
\end{abstract}

Key words: mechanism, the strategic staffing gaps, human resources, staffing, region, stakeholders.

Постановка проблеми у загальному вигляді та ії зв'язок з важливими науковими і практичними завданнями. Раціональне використання кадрових ресурсів грає істотну роль у формуванні сталого економічного розвитку території. Від того, наскільки ефективним $\epsilon$ кадрове забезпечення регіону, багато в чому залежить економічний потенціал кожної ланки господарської діяльності, зміцнення конкурентних позицій регіону, зростання рівня життя населення та інше.

На сьогоднішній день в основному відбувається інерційний характер існування регіонів України, детермінують наступні негативні явища кадрового забезпечення країни в цілому: істотне перевищення пропозиції робочої сили над попитом на неї, збільшення частки дефіцитних професій, низька вартість робочої сили, високий рівень неформальної та тимчасової незайнятості тощо. Саме тому, в розрізі сталого економічного розвитку територій, особливого значення набуває розробка механізму, дія якого буде спрямована на підвищення ефективності використання кадрових ресурсів за умови наявного кадрового забезпечення.

Аналіз останніх досліджень, у яких започатковано вирішення проблеми. Глибокий внесок у питання формування механізму кадрового забезпечення внесли такі вчені та науковці, як Р.Л. Дафт, Е. У. Демінг, В.Л.Решетняк, А.Л.Скрипник, В.А.Співак, А.Л. Шевчук та інші. Однак недостатньо розробленими залишаються питання вивчення та розробки механізму управління стратегічними розривами кадрового забезпечення 3 урахуванням конкурентних переваг окремого регіону.

Цілі статті. Мета статті полягає в обгрунтуванні механізму управління стратегічними розривами кадрового забезпечення на прикладі Харківського регіону. 
Виклад основного матеріалу дослідження 3 обгрунтуванням отриманих наукових результатів. Механізм управління стратегічними розривами кадрового забезпечення розвитку регіону являє собою складну інтегровану систему, що складається з принципів, методів, форм, функцій, алгоритмів дій, тощо, взаємоузгоджене впровадження та реалізація яких здатні забезпечити раціональне використання кадрових ресурсів території.

Кадрові ресурси Харківського регіону є обмеженими: оскільки станом на 2018 р. на регіональному ринку праці за видами економічної діяльності було зайнято 1213,3 тис. осіб (майже 45\% наявного населення регіону) [1]. Також розподіл кадрових ресурсів за видами економічної діяльності має кількісні обмеження існуючих та перспективних робочих місць, тому в механізм управління стратегічними розривами кадрового забезпечення розвитку регіону закладаються обмеження у вигляді наявного кадрового забезпечення та ранжування напрямків здійснення професійної діяльності за критеріями розміру створеної валової доданої вартості. У якості показника, що оцінює співвідношення зазначених обмежень виступає продуктивність праці за секторами економіки регіону. Таким чином, на «виході» зазначеної моделі є ефективний розподіл наявного кадрового забезпечення, що дає змогу забезпечити ефективне використання кадрових ресурсів, виходячи з потреб зростання продуктивності праці до світового рівня. Економічний сенс побудови зазначеного механізму полягає в управлінні стратегічними розривами кадрового забезпечення розвитку регіону 3 метою забезпечення сталого розвитку території.

Головною метою розробки зазначеного механізму - $\epsilon$ формування перспективної структури кадрових ресурсів, необхідної якості та кількості, 3 урахуванням конкурентних переваг регіону.

Основою для розробки напрямків 3 підвищення ефективності використання кадрових ресурсів є комплексний аналіз резервів їх використання [2, с. 50]. Резерви підвищення ефективності використання кадрових ресурсів умовно можна поділити на три групи залежно від чинників, що їх детермінують: матеріально-технічні, організаційноекономічні та соціально-економічні.

Резерви матеріально-технічної групи пов'язані з функціонуванням основних фондів підприємств, організацій, закладів освіти, охорони здоров'я тощо, що здійснюють свою діяльність за різними видами економічної діяльності регіону. Зазначені резерви являють собою можливості щодо трудозберігання на робочому місці.

Організаційно-економічні резерви формуються за рахунок ефективної організації системи виробництва або надання послуг за різними секторами економіки регіону, використання робочої сил, ефективного функціонування існуючих робочих місць та створення нових тощо.

Резерви, формування яких обумовлено соціально-економічними чинниками передбачають можливість щодо трансформації функціонального, професійного та освітнього рівнів структури кадрових ресурсів. Також до групи зазначених резервів входять ті, що формуються за умови дії матеріальних та нематеріальних стимулів до праці, справедливості розподілу доходів й забезпечення гідних умов праці та інше.

В розрізі трансформації виробничих домінант в умовах економіки 4.0, відповідно до проведеного дослідження передумов [3, С. 117-122], що детермінують розриви кадрового забезпечення території, був сформований ряд напрямків підвищення ефективності використання кадрових ресурсів (рис.1):

- формування ефективної структури зайнятості, відповідно до потреб різних видів економічної діяльності регіону;

- розвиток якісних характеристик кадрових ресурсів, виходячи з глобальних тенденцій, що формують сучасне робоче місце;

- визнання та використання інтелектуального та трудового потенціалу мігрантів;

- встановлення довгострокових партнерських відносин 3 зацікавленими сторонами кадрового забезпечення розвитку регіону. 
Реалізація механізму управління стратегічними розривами кадрового забезпечення розвитку регіону вимагає сприяння, підтримки і співпраці всіх груп зацікавлених сторін, що дозволяє їх визначити у якості суб'єктів ефективного використання кадрових ресурсів. Об'єктом використання виступають кадрові ресурси регіону.

Невід'ємними елементами механізму управління стратегічними розривами кадрового забезпечення розвитку регіону, що формуються відповідно до головної мети і напрямків її реалізації $є$ принципи та завдання.

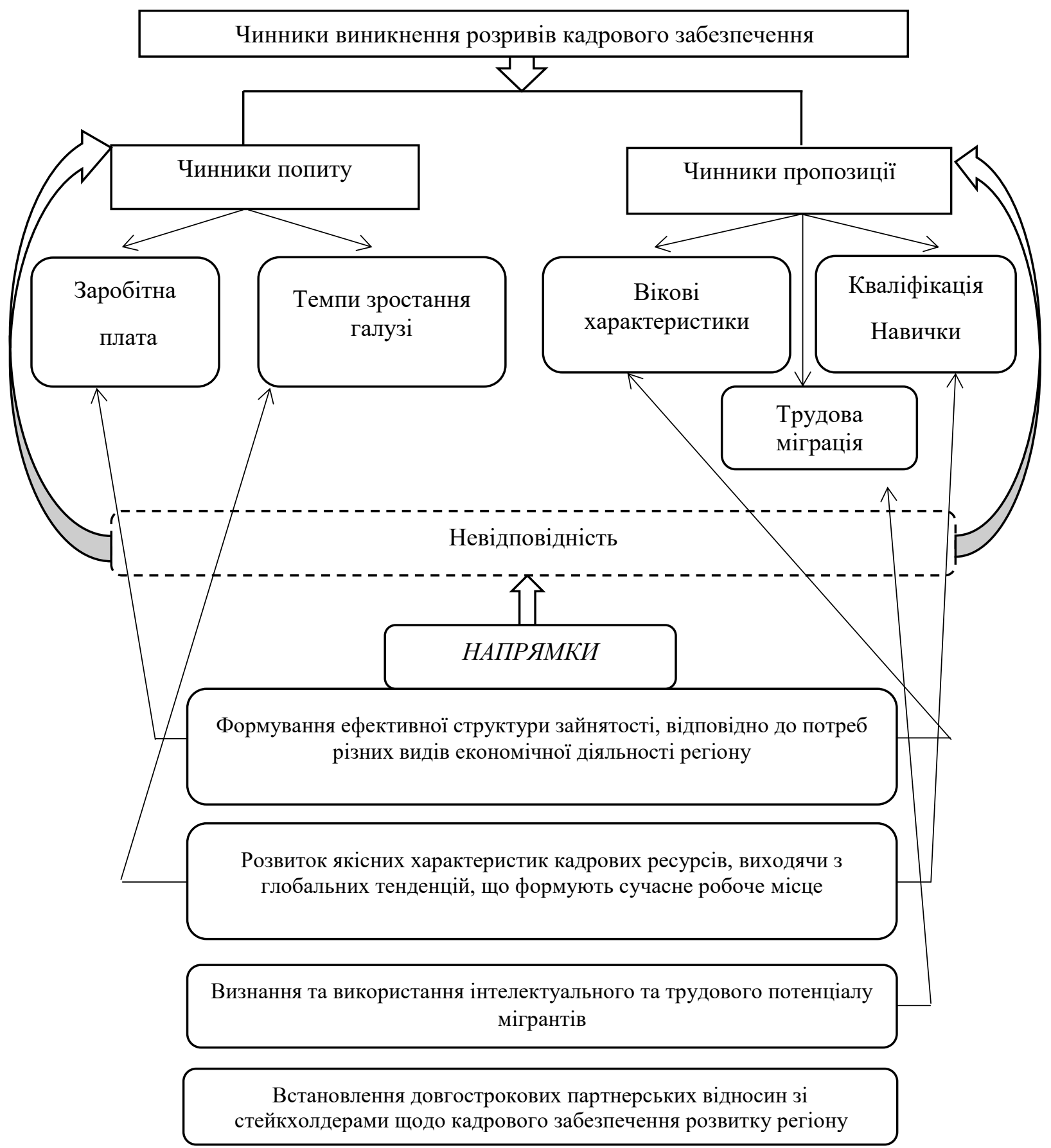

Рис. 1. Напрямки управління стратегічними розривами кадрового забезпечення розвитку регіону (розроблено авторами) 
Основні принципи формування перспективної структури кадрових ресурсів походять від загальних принципів управління, до яких належать принципи системності, об'єктивності, актуальності, комплексності, науковості, інформаційної забезпеченості тощо [4, с. 250]. Також окремо в механізм управління стратегічними розривами кадрового забезпечення розвитку необхідно включити класичні принципи управління потенціалом кадрових ресурсів, а саме (рис.2):

1. Принцип ефективності найму, відбору та розстановки персоналу

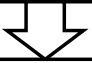

2. Принцип справедливості розподілу навантаження, оплати праці за ії результатами

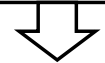

3. Принцип стимулювання праці та підвищення кваліфікаційного рівня кадрів

Принцип можливості професійного зростання у відповідності до результатів праці, рівня кваліфікації, здібностей, особистих інтересів тощо

Рис. 2. Принципи управління потенціалом кадрових ресурсів (побудовано авторами на основі даних [5, с. 352])

За напрямком встановлення довгострокових партнерських відносин зі стейкхолдерами території, окрім раніше зазначених принципів, доцільним $є$ грунтування на основі специфічних принципів процесу залучення зацікавлених сторін до вирішення існуючої проблеми [6]:

-суттєвість (першочерговість знань про те, що є важливим для розвитку території і її стейкхолдерів);

-повнота (вимагає розуміння управління матеріальними наслідками та пов'язаними з ними очікуваннями стейкхолдерів);

-чуйність (вимагає узгодженого реагування на запити стейкхолдерів).

Що стосується завдань функціонування механізму управління стратегічними розривами кадрового забезпечення розвитку регіону, розв'язання яких має забезпечити вирішення існуючої проблеми, то наукові пошуки у розрізі стратегічного управління кадровими ресурсами дозволили виділити найбільш значущі з них.

За напрямком «формування ефективної системи зайнятості, відповідно до потреб різних видів економічної діяльності регіону» першочерговими завданнями мають стати:

-прогнозування потреб у кадрових ресурсах відповідно до світових та всеукраїнських тенденцій за видами економічної діяльності;

-перерозподіл кадрових ресурсів з секторів економіки регіону, для яких характерним $є$ висока частка зайнятих при низьких темпах зростання продуктивності праці, в перспективні сектори розвитку регіону;

-підтримка та сприяння розвитку видів економічної діяльності регіону (здебільшого тих, що надають неринкові послуги) з критичною ситуацією на ринку праці;

-збереження робочих місць, що ефективно функціонують та створення нових;

-зниження рівня безробітних серед працездатного населення регіону та скорочення тривалості зареєстрованого безробіття; 
- забезпечення соціального захисту та надання додаткових гарантій для кадрових ресурсів при працевлаштуванні, здійснені професійної діяльності та завершення кар'єри;

-поліпшення міжнародного співробітництва, у тому числі, залучення міжнародних коштів, шляхом отримання відповідних грантів для покращення існуючої системи фінансування та управління кадровим забезпеченням розвитку регіону;

-концентрація коштів на пріоритетних напрямках підвищення ефективності кадрового забезпечення за рахунок впровадження вибіркового фінансування технічних завдань;

-та інше.

Реалізація напрямку «розвиток якісних характеристик кадрових ресурсів, виходячи 3 глобальних тенденцій, що формують сучасне робоче місце» потребує виконання наступних завдань:

-нарощування освітньо-кваліфікаційного потенціалу кадрових ресурсів;

-розвиток систем підготовки, підвищення кваліфікації та перепідготовки кадрових ресурсів;

-розробка адаптованої до місцевих умов політики щодо навичок;

-впровадження концепції «Навчання протягом життя»;

-поширення серед населення регіону інноваційних форм зайнятості;

-збільшення зайнятості шляхом встановлення мережі контактів університетів 3 приватним сектором: розробка мережі публічно-приватного партнерства;

-та інші.

За напрямком «визнання та використання інтелектуального та трудового потенціалу мігрантів» сформовані наступні завдання:

-визнання навичок трудових мігрантів, що були здобуті за кордоном;

-підвищення кваліфікації або надолуження навичок, що були втрачені в результаті праці кадрових ресурсів регіону за кордоном не за фахом;

-розробка програми повернення тих емігрантів, в яких вже сформована чи потенційно буде сформована готовність до рееміграції;

-та інші.

Напрямок «встановлення довгострокових партнерських відносин з зацікавленими сторонами кадрового забезпечення у розвитку регіону» вимагає вирішення наступних завдань:

-ідентифікація стейкхолдерів сталого економічного розвитку регіону;

-залучення зацікавлених сторін до процесу підвищення ефективності кадрового забезпечення розвитку регіону;

-моніторинг сумісної праці та управління стейкхолдерами;

-та інше.

Відповідно до заявлених завдань у якості функції механізму управління стратегічними розривами кадрового забезпечення розвитку регіону виступають наступні: аналітична, навчальна та стимулююча, інформативно-комунікаційна та оцінка кадрових ресурсів. Більш детальна характеристика визначених функцій зазначеного механізму представлена на рис. 3.

Форми механізму управління стратегічними розривами кадрового забезпечення розвитку регіону уявляють собою зовнішній вираз способів, змісту, умов, порядку і послідовності його реалізації, з метою формування перспективної структури кадрових ресурсів, з урахуванням конкурентних переваг регіону. Отже, до основних форм реалізації зазначеного механізму можна віднести: регіональну кадрову політику; заходи регіональної служби зайнятості 3 підвищення конкурентоспроможності кадрових ресурсів; адміністративно-економічного регулювання розвитку регіону тощо [8, с. 48]. 
До основних методів реалізації механізму управління стратегічними розривами кадрового забезпечення розвитку регіону відносяться нормативно-правові, адміністративні, економічні та соціально-психологічні.

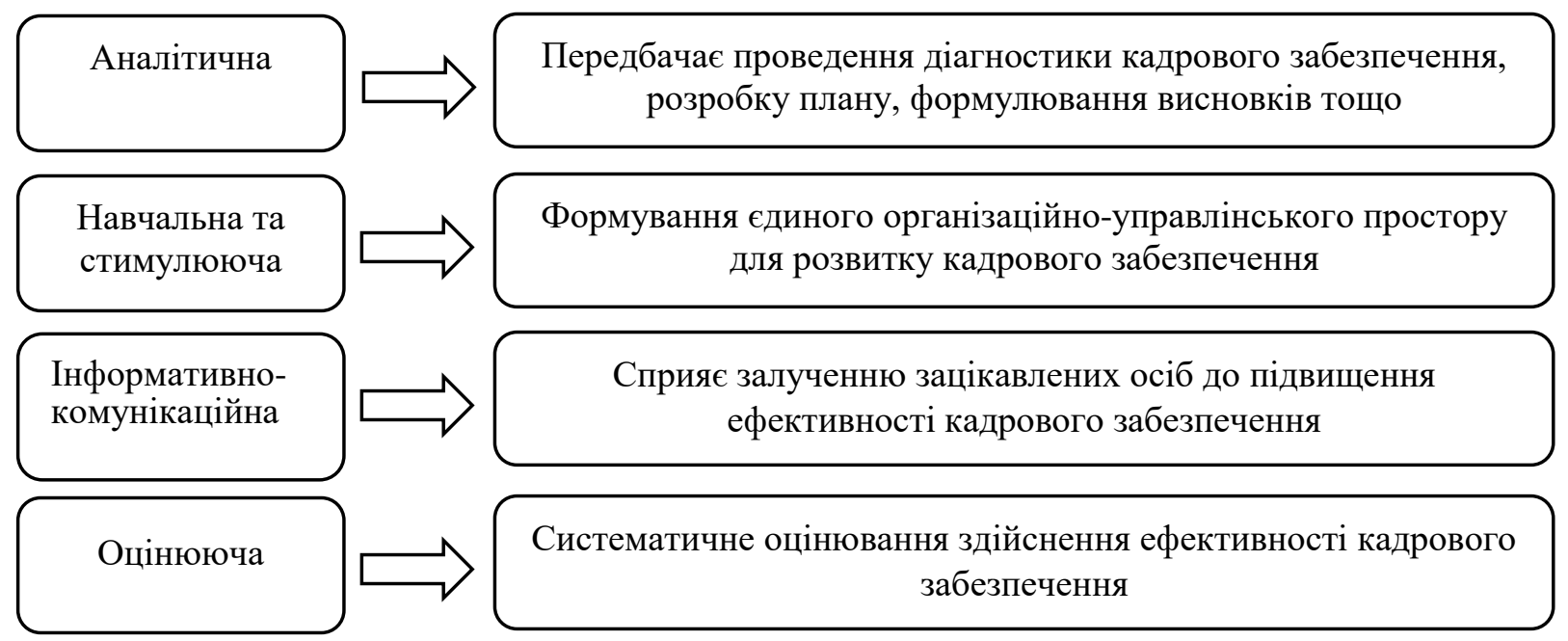

Рис.3. Характеристика функцій механізму управління стратегічними розривами кадрового забезпечення розвитку регіону (адаптовано авторами на основі даних [7, c.122])

Інструментами реалізації механізму $\epsilon$ також неформальні інструменти професійного навчання кадрових ресурсів за видами економічної діяльності (наставництво, менторство, коучинг тощо).

Також окремо слід визначити методи реалізації управління стратегічними розривами кадрового забезпечення розвитку регіону, що пов'язані з залученням зацікавлених сторін з метою досягнення сталого економічного розвитку регіону, i уявляють собою похідну від загальних методів управління стейкхолдерами території. Вважається, що найбільш ефективними методами залучення зацікавлених сторін $\epsilon$ «делегована влада», «партнерство», «співпраця» та «участь», що детермінують процеси спільного прийняття рішень. На сьогоднішній день, найбільш поширеними методами управління стейкхолдерами в процесі реалізації концепції децентралізації з метою досягнення сталого економічного розвитку території $\epsilon$ «участь», «переговори» та «консультації». Саме тому, на шляху до реалізації механізму управління стратегічними розривами кадрового забезпечення розвитку регіону актуальним $\epsilon$ залучення зацікавлених сторін до більш свідомих, ініціативних та відповідальних спільних рішень. Серед головних інструментів реалізації методів ефективного залучення стейкхолдерів в рамках зазначеного механізму можна виділити наступні: громадські слухання, створення спільних проектів, делегування повноважень, конструктивний діалог та інші.

В процесі розробки механізму управління стратегічними розривами кадрового забезпечення розвитку регіону, не менш важливим є врахування умов зовнішнього середовища та внутрішніх факторів. Під впливом яких, може відбутися деградація якісних та кількісних характеристик кадрових ресурсів, у тому числі [9, с. 179]:

- вимушена зайнятість кваліфікованих кадрових ресурсів в сферах діяльності 3 низькими вимогами щодо освітньо-професійного рівня;

- тимчасова трудова міграція (праця не за фахом за кордоном);

- старіння знань під впливом НТП;

- зростання продуктивності праці за рахунок технологій;

- поширення аутсорсингових моделей ведення бізнесу; 
- скорочення циклів життя технологій та інше.

При цьому, фактори зовнішнього середовища, як правило, не можуть бути вирішені на регіональному та навіть світовому рівні, адже вони носять еволюційний характер та поглиблюються за рахунок розвитку технологій. Під впливом таких протиборчих факторів як технологічний прогрес, демографічні зрушення, стрімка урбанізація, зміни в глобальній економіці тощо, відбувається трансформація в структурі, формі і навіть характері праці [10]. Саме тому, має місце, адаптація кадрового забезпечення на регіональному рівні відповідно до викликів зовнішнього середовища.

У той час, як внутрішні фактори (професійне навчання, фінансові ресурси, розвиток навичок, виходячи 3 потреб роботодавців тощо) піддаються впливу з боку зацікавлених сторін та самих кадрових ресурсів.

Графічно механізм управління стратегічними розривами кадрового забезпечення розвитку регіону, з урахуванням визначених структурних елементів, можна зобразити наступним чином (рис.4):

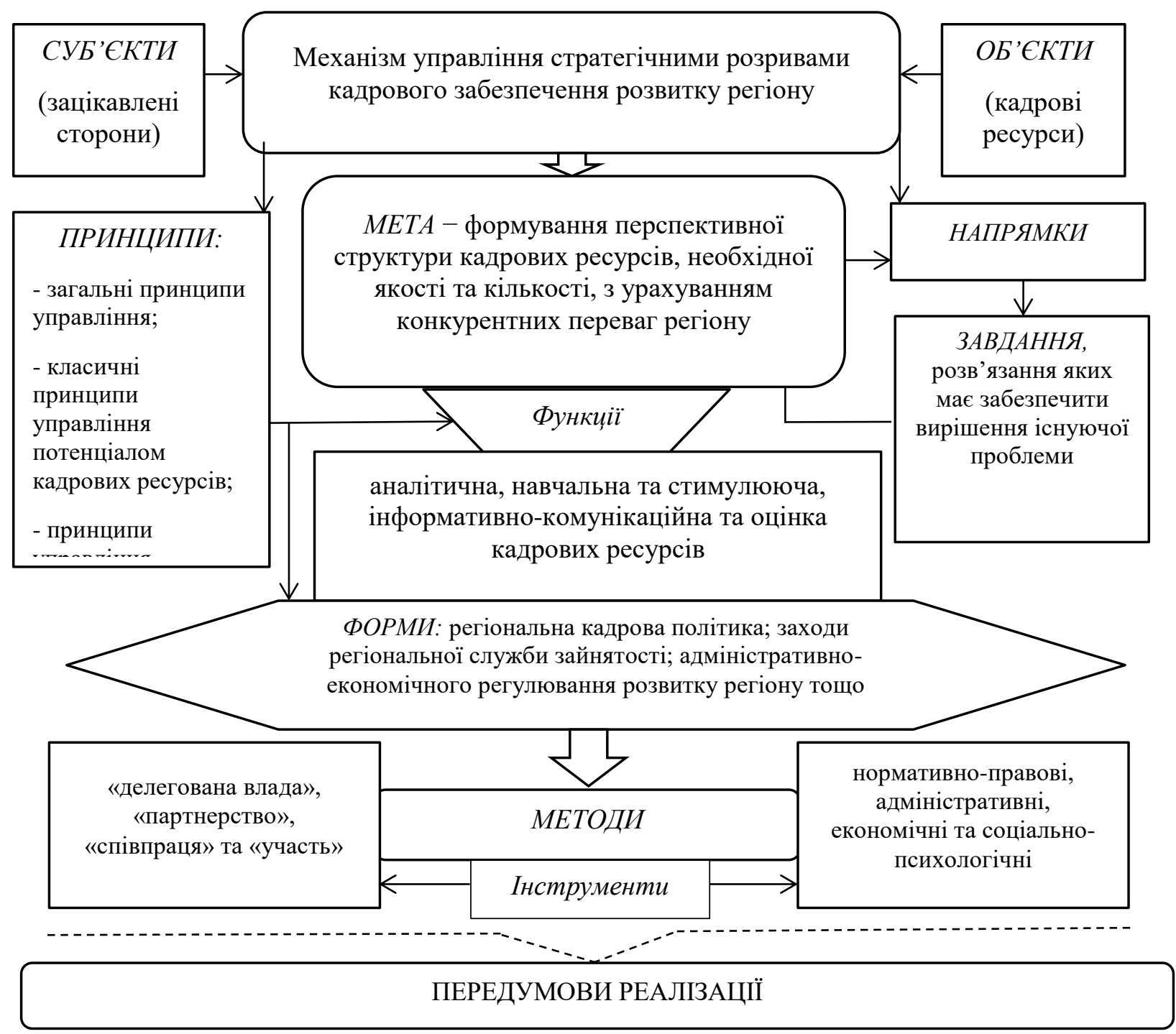

Рис. 4. Механізм управління стратегічними розривами кадрового забезпечення розвитку регіону (розроблено авторами)

Однією з головних перешкод, що може стояти на шляху до реалізації механізму управління стратегічними розривами кадрового забезпечення розвитку регіону є брак 
інвестицій та дефіцит державного фінансування на розвиток кадрових ресурсів. Питання залучення інвестицій частково можна бути вирішити за рахунок участі регіону у міжнародних грантових програмах, залучення стейкхолдерів, зокрема бізнесу, для подолання розривів кадрового забезпечення території [11, с. 72]. Що стосується законодавчих важелів покрашення існуючої системи фінансування кадрового забезпечення регіонів, то пропонується встановити відсоток витрат для місцевих бюджетів, на рівні 1\%, що мають бути спрямовані на реалізацію проектів з розвитку кадрового забезпечення та подолання «стратегічних розривів» на рівні регіону. Така норма сприятиме активізації регіональних агентів кадрового забезпечення.

Висновки з цього дослідження і перспективи подальших розвідок у даному напрямку. Таким чином, сформований механізм управління стратегічними розривами кадрового забезпечення розвитку регіону, детермінує реалізацію інтересів суб'єктів та об'єкта системи кадрового забезпечення. Окрім цього, зазначений механізм багато в чому детермінує інвестиційну привабливість території, іiі підприємницький клімат та ступінь його використання, конкурентну позицію на локальному ринку та ефективність органів місцевої влади.

Зростання динамічності економічного життя, швидке старіння знань та вмінь працівників, технологічний тиск на робочі місця, погіршення демографії посилюють невідповідність потреби в кадрах тому кадровому потенціалу, який сформовано чи має бути сформовано на рівні кожної ланки господарської діяльності. За таких умов впровадження механізму управління стратегічними розривами кадрового забезпечення розвитку регіону та підтримання кадрового забезпечення території на високому рівні стає актуальним завданням для всієї країни.

Вважаємо, що практична реалізація зазначеного механізму не тільки сприятиме подоланню розривів кадрового забезпечення Харківського регіону, але й в довгостроковій перспективі дозволить зміцнити конкурентні позиції регіону на національному та міжнародному ринках.

\section{Список бібліографічного опису:}

1. Державна служба статистики України. URL: http://www.ukrstat.gov.ua/ (дата звернення 10.02.2020).

2. Співак В. А. Результативність організаційно-економічного механізму кадрового забезпечення як чинник інвестиційної привабливості України. Формування ринкових відносин в Украӥні: зб. наук. праць. 2004. №33. С. 47-51.

3. Рекун Г.П., Меденець В.В. Передумови виникнення розривів у кадровому забезпеченні розвитку регіонів. Бізнес Інформ. 2019. №9. С. 117-122.

4. Дафт Р.Л. Уроки лидерства. Москва: Эксмо, 2008. 480 с.

5. Деминг Э.У. Выход из кризиса. Новая парадигма управления людьми, системами и процессами. Москва: Альпина Паблишер, 2014. 620 c.
6. The stakeholder
engagement manual
volume
2. URL:
http://www.mas-

business.com/docs/English\%20Stakeholder\%20Engagement\%20Handbook.pdf (last access: 08.03.2020).

7. Ульрих Д. Эффективное управление персоналом. Новая роль HR-менеджера в организации. Москва: Вильямс, 2007. 304 c.

8. Скрипник А. Л. Методичні підходи до оптимізації організаційно-економічного механізму кадрового забезпечення в умовах формування ринкових відносин. Формування ринкових відносин в Україні: зб. наук. праць. 2003. №30. С. 47-52.

9. Решетняк В. Л. Теоретичні засади вдосконалення організаційно-економічного механізму забезпечення керівними кадрами. Київ: Приор, 2008. С. 177-182.

10. Майбутнє ринку праці. Міжнародна практика PwC. URL: https://www.pwc.com/ua/uk/survey/2018/workforce-of-thefuture-ukr.pdf (дата звернення 20.02.2020).

11. Шевчук А. Л. Вдосконалення механізму кадрового забезпечення як фактор розвитку підприємництва в Україні. Підприємництво як сочіально - економічна передумова становлення середнього класу: зб. доповідей та тез Міжнар. наук. - практ. конференції. Харків, 2008. С. 71-75.

\section{References:}

1. Derzhavna sluzhba statystyky Ukrayiny. Available at: http://www.ukrstat.gov.ua/ (accessed 10.02.2020). [in Ukrainian]. 2. Spivak V. A. Rezul'tatyvnist' orhanizatsiyno-ekonomichnoho mekhanizmu kadrovoho zabezpechennya yak chynnyk investytsiynoyi pryvablyvosti Ukrayiny. Formuvannya rynkovykh vidnosyn v Ukrayini: zb. nauk. prats', 2004, no.33, pp. 4751. [in Ukrainian].

3. Rekun H.P., Medenets' V.V. Peredumovy vynyknennya rozryviv u kadrovomu zabezpechenni rozvytku rehioniv. Biznes Inform, 2019, no. 9, pp. 117-122. [in Ukrainian]. 
4. Daft R.L. Uroki liderstva. Moscow, Eksmo, 2008. 480 p. [In Russian].

5. Deming E.U. Vyhod iz krizisa. Novaya paradigma upravleniya lyudmi, sistemami i processami. Moscow, Alpina Pablisher, 2014. 620 p. [In Russian].

6. The stakeholder engagement manual volume 2. Available at: http://www.masbusiness.com/docs/English\%20Stakeholder\%20Engagement\%20Handbook.pdf (accessed 08.03.2020).

7. Ulrih D. Effektivnoe upravlenie personalom. Novaya rol HR-menedzhera v organizacii. Moscow,Vilyams, 2007. 304 p. [In Russian].

8. Skrypnyk A. L. Metodychni pidkhody do optymizatsiyi orhanizatsiyno-ekonomichnoho mekhanizmu kadrovoho zabezpechennya $\mathrm{v}$ umovakh formuvannya rynkovykh vidnosyn. Formuvannya rynkovykh vidnosyn v Ukrayini: zb. nauk. prats', 2003, no. 30, pp. 47-52. [in Ukrainian].

9. Reshetnyak V. L. Teoretichni zasadi vdoskonalennya organizacijno-ekonomichnogo mehanizmu zabezpechennya kerivnimi kadrami. Kiev, Prior, 2008. pp. 177-182. [in Ukrainian].

10. Maybutnye rynku pratsi. Mizhnarodna praktyka PwC. Available at: https://www.pwc.com/ua/uk/survey/2018/workforceof-the-future-ukr.pdf (accessed 20.02.2020). [in Ukrainian].

11. Shevchuk A. L. Vdoskonalennya mekhanizmu kadrovoho zabezpechennya yak faktor rozvytku pidpryyemnytstva $\mathrm{v}$ Ukrayini. Zb. dopovidey ta tez Mizhnar. nauk. - prakt. konferentsiyi "Pidpryyemnytstvo yak sotsial'no - ekonomichna peredumova stanovlennya seredn'oho klasu”. Kharkiv, 2008, pp. 71-75. [in Ukrainian].

Дата подання публікації 27.04.2020

УДК 336.153.11

Стельмах Х. П., к.е.н., науковий співробітник Stelmakh K. Candidate of Economic Sciences, Researcher JELF01,O4, R11

\title{
ОСОБЛИВОСТІ КОНКУРЕНТОСПРОМОЖНОСТІ РЕГІОНІВ УКРАЇНИ
}

\author{
ДУ «Інститут регіональних досліджень ім. М. І. Долішнього НАН України»
}

В статті розглянуто особливості конкурентоспроможності регіонів, визначено чинники, що ії формують. Вивчення конкурентоспроможності регіонів $є$ дуже важливим та актуальним питанням, адже це одна з основних рис економічного життя країни. Визначено, що суть конкурентоспроможності має міждисциплінарний характер і ії головне призначення отримати перевагу порівняно з іншими суб'єктами, із створенням кращих умов в регіоні для задоволення потреб мешканців. Поточна і майбутня конкурентна позиція регіону є результатом переваги перед конкурентами регіонами. Визначення ступеня привабливості регіону для бізнесу та інвесторів - це результат визначення його позиції конкурентних переваг з точки зору наявних чинників конкурентоспроможності та оцінювання конкурентних переваг. Оцінювання свої сильних сторін та подолання слабких сторін $\epsilon$ можливо завдяки використанню регіоном своїх конкурентних переваг та фінансових можливостей. Швидка інтеграція світової економіки стала причиною пошуку відповіді на питання про те, які чинники конкурентоспроможності визначають успіх деяких регіонів, а інші, що працюють в однакових умовах не мають переважаючих результатів. Основою дослідження конкурентоспроможності $\epsilon$ детальне вивчення чинників макрорівня, мезо-рівня та макрорівня, а також особливостей іiі формування на підставі економічних складових. Ключовими чинниками конкурентоспроможності є собівартість продукції, якість товарів та послуг, стратегії розвитку регіонів, глобалізація, функціонування професійних об'єднань, наявність стимулів для розвитку підприємництва, нормативно-правова база господарювання, політична ситуація.

Ключові слова: конкурентоспроможність, конкурентні переваги, чинники конкурентоспроможності, прикордонні території, регіони, особливості конкурентоспроможності.

\section{THE FEATURES OF COMPETITIVE ABILITY OF UKRAINIAN REGIONS}

\author{
Institute of Regional Research named after M.I. Dolishniy of the NAS of Ukraine
}

The paper examines the peculiarities of competitive ability of border regions and the factors that form it as well as provides the evaluation of competitive advantages. Study of competitive ability of regions is very 
important and relevant issues as it is one of the major features of economic life. The paper proves that competitive 